\title{
Diel vertical migration of sea scallop larvae Placopecten magellanicus in a shallow embayment
}

\author{
M. John Tremblay ${ }^{1}$, Michael Sinclair ${ }^{2}$ \\ ${ }^{1}$ Fisheries and Oceans, Biological Sciences Branch, PO Box 550, Halifax, Nova Scotia, Canada B3J 2S7 \\ ${ }^{2}$ Bedford Institute of Oceanography, PO Box 1006, Dartmouth, Nova Scotia, Canada B2Y 4A2
}

\begin{abstract}
Vertical distribution of sea scallop larvae was studied while anchored for 50 h at a shallow location $(<25 \mathrm{~m}$ ) off Grand Manan Island in the outer Bay of Fundy. Changes in the depth-averaged concentration of larvae (no. $\mathrm{m}^{-3}$ ) were unrelated to changes in the centre of mass (ZCM) of larvae, and appear to reflect the movement of a patch (or patches) of larvae back and forth past the anchor station. A small-amplitude diel vertical migration, comparable to observations under controlled conditions, was indicated by changes in the ZCM. During the day the ZCM ranged from 5.2 to $11.5 \mathrm{~m}$, while at night the ZCM was shallower and less variable $(4.1$ to $6.8 \mathrm{~m})$. The concentration of all size groups was greatly reduced within 1 to $8 \mathrm{~m}$ of the bottom, and evidence for vertical stratification by size was lacking. Sea scallop larvae appear to be unable to form aggregations below a critical level of water column stratification.
\end{abstract}

\section{INTRODUCTION}

The distribution of marine planktonic larvae is largely a function of the direction and strength of the currents in which they are carried, coupled with the location of larval origin. As models of the physical circulation improve, there is a need to better understand what role larval behavior plays in determining their vertical distribution. Whether the larvae undertake active vertical migrations must be known, since modelling studies show that this can alter the pattern of planktonic dispersal from that expected from physical processes alone (Kamykowski 1976, Rothlisberg 1982, Rothlisberg et al. 1983, Lough \& Trites 1989).

Vertical migration by some species of bivalve larvae may be significant despite their small size $(<300 \mu \mathrm{m})$ and low vertical swimming speeds (generally $<2.0 \mathrm{~mm} \mathrm{~s}^{-1}$; Mileikovsky 1973, Cragg 1980, Mann \& Wolf 1983). Active migration of late stage oyster larvae in relation to tidal circulation within some estuaries has been reported (Nelson \& Perkins 1931, Carriker 1951, Kunkle 1958), although there are other interpretations of these data which do not involve larval behavior (Korringa 1952, de Wolf 1973, Andrews 1983). Diel vertical migration of some coastal bivalve larvae (Quayle 1952, 1959, Verwey 1966, Harding et al. 1986), and offshore bivalve larvae (Scrope-Howe \& Jones
1986) is suggested by the occurrence of the larvae in shallower depths at night.

Pectinid larvae in mesocosms migrate to shallower waters at night (Kaartvedt et al. 1987, Silva \& O'Dor 1988) but there are no published field studies to corroborate these findings. On Georges Bank, a diel vertical migration of sea scallop larvae Placopecten magellanicus could not be detected, but the $10 \mathrm{~m}$ sampling intervals may have been too coarse (Tremblay \& Sinclair 1990). In the present paper we investigate whether sea scallop larvae vertically migrate in a shallow embayment in the outer Bay of Fundy.

\section{METHODS}

Scallop larvae were collected for $50 \mathrm{~h}$ from 3 to 5 October 1985 from a ship anchored within an embayment of Grand Manan Island at the mouth of the Bay of Fundy (Fig. 1). The site was chosen because of its weak tidal currents in comparison with other locations in the Bay of Fundy, a feature which made depth-stratified sampling via pump possible. Bottom depth at the site ranged between 20 and $24 \mathrm{~m}$ depending on the tide. Sampling took place every $2 \mathrm{~h}$, for a total of 26 profiles.

The pump system used for sampling scallop larvae consists of a FLYGT model 2051 electric pump, $6 \mathrm{~cm}$ 


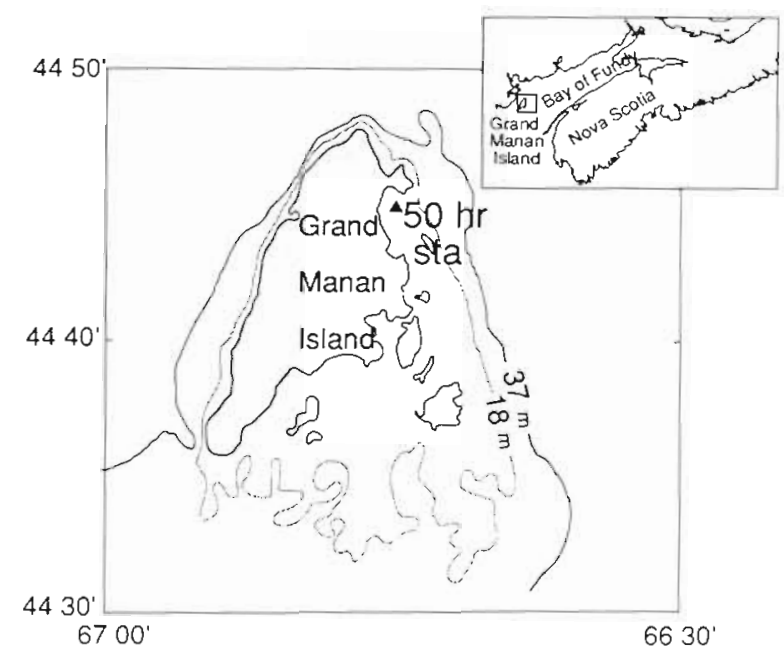

Fig. 1. Grand Manan Island and location of $50 \mathrm{~h}$ anchor station

suction hose and a SIGNET in-line flowmeter and readout. The pump intake was attached to a hydrographic wire and moved vertically through a depth interval of 5 to $9 \mathrm{~m}$ for 6 to $10 \mathrm{~min}$ until a sample of 2 to $3.5 \mathrm{~m}^{3}$ (mean: 2.7) was obtained. Four depth intervals were sampled every $2 \mathrm{~h}: 0.5$ to $5 \mathrm{~m}, 5.5$ to $10 \mathrm{~m}, 10.5$ to $15 \mathrm{~m}$, and $15.5 \mathrm{~m}$ to within 0.5 to $1.0 \mathrm{~m}$ of the bottom. For the last profile only, samples were obtained at $2 \mathrm{~m}$ intervals to a depth of $24 \mathrm{~m}$.

On deck, the pump outflow was directed first through a coarse mesh net $(333 \mu \mathrm{m})$ to remove larger particles, and then through a fine mesh net $(85 \mu \mathrm{m})$ for sample collection. Samples were preserved in $4 \%$ formalin buffered with sodium borate. Sea scallop larvae and other heavier components of the plankton samples were physically separated from the lighter components using a colloidal silica (Tremblay et al. 1987). All sea scallop larvae in the samples were then identified and counted using a dissecting microscope. After transferring the larvae from the counting dish to a welled slide. the lengths of the larvae were measured to the nearest $6 \mu \mathrm{m}$ using an inverted microscope.

Once every $2 \mathrm{~h}$, in between larval profiles, an Aanderaa RCM4S current meter was lowered through the water column to measure current speed and direction, temperature, and conductivity. Measurements were made at $2 \mathrm{~m}$ intervals to a depth of 18 to $22 \mathrm{~m}$ depending on the water depth. Unless otherwise noted, current speed refers to the average from the surface to 18 or $20 \mathrm{~m}$. Tidal height was obtained from tide tables for Saint John, N.B., Canada, prepared by the Canadian Hydrographic Service.

Data analyses. To reflect the mean depth of sea scallop larvae for any given profile, the centre of mass (ZCM) was calculated as in Fortier \& Leggett (1982):

$$
\mathrm{ZCM}=\sum_{i=1}^{\mathrm{n}} \mathrm{p}_{i} \mathrm{z}_{i}
$$

where $\mathrm{p}_{i}=$ proportion of the total number of larvae caught within the $i$ th depth interval; and $z_{i}=$ middepth of the $i$ th interval. The centre of the deepest interval was taken as $18 \mathrm{~m}$. As a measure of larval aggregation, the coefficient of variation (CV) of the concentration of larvae over the 4 depth intervals was used. A high CV indicates strong aggregation of larvae while a low $\mathrm{CV}$ indicates that the larvae are more evenly distributed over the water column.

The structure of the water column during each physical profile over the $50 \mathrm{~h}$ was characterized by the depth of the pycnocline and by the level of density stratification. Pycnocline depth (P) was estimated as the centre of the $6 \mathrm{~m}$ interval where the chance in sigma-t was maximum. An index of the density stratification of the water column (S) from the surface to 18 to $20 \mathrm{~m}$ was calculated as:

$$
S=\Delta \text { sigma }-t / \Delta Z
$$

where $Z=$ depth.

All statistical analyses were done with SYSTAT.

\section{RESULTS}

Vertical differences in temperature in the water column were small, with mean temperatures over the sampling period of $11.8^{\circ} \mathrm{C}$ at the surface and $11.3^{\circ} \mathrm{C}$ at $22 \mathrm{~m}$ (Fig. 2a). Density structure was primarily a function of the temperature structure, and the water column

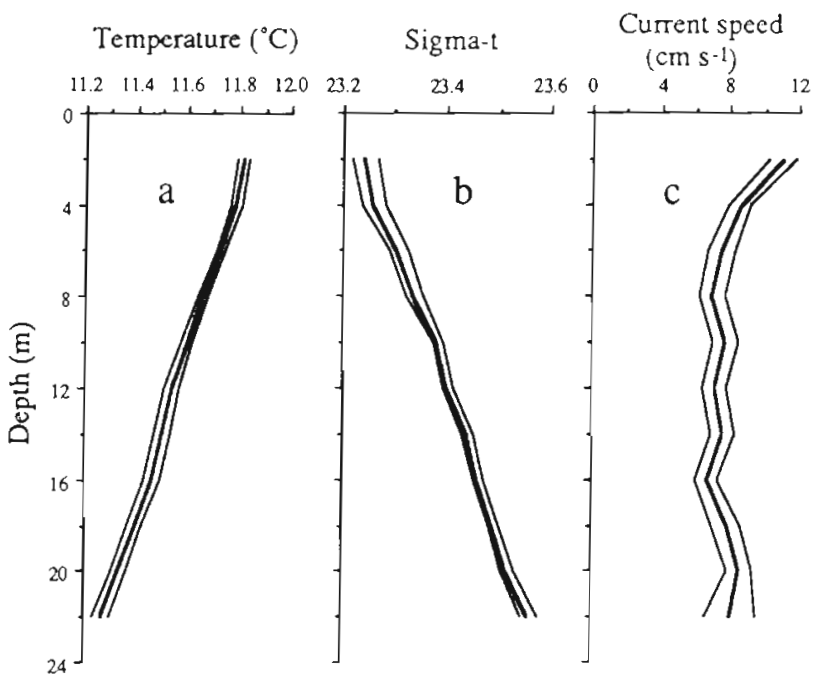

Fig. 2. Composite profiles of (a) temperature, (b) sigma-t, and (c) current speed at the anchor station. Bold line is the mean of all profiles completed over the $50 \mathrm{~h}$. Lighter lines show plus or minus one standard error Based on 26 profiles for temperature and 25 for current speed and sigma-t 
was weakly stratified with a poorly defined pycnocline (Fig. 2b). Mean current speeds were fairly uniform with depth, ranging between 6 and $12 \mathrm{~cm} \mathrm{~s}^{-1}$ (Fig. 2c). The higher speed at $2 \mathrm{~m}$ was due both to wind and some pumping by the ship which was unrelated to the study.

Sea scallop larvae were usually most concentrated in the upper $10 \mathrm{~m}$, with sharply reduced densities below $15 \mathrm{~m}$ (Fig. 3). Strong aggregations within the upper $5 \mathrm{~m}$ were limited to night profiles, while aggregations below $10 \mathrm{~m}$ were limited to day profiles (Fig. 3). A rise in the larval centre of mass (ZCM) occurred between $19: 30$ and $21: 30 \mathrm{~h}$ on both days, and a lowering of the ZCM occurred between 07:30 and 09:30 h (Fig. 4a). Over the $50 \mathrm{~h}$ of sampling, the ZCM was shallower during the night than the day, and occurred within a narrower depth interval (Figs. 3 and $4 a$, Table 1).

Although current speed and density stratification (S) were more variable during the day, there were no significant day-night differences in these physical variables to parallel the differences in the ZCM (Table 1). The ZCM was not correlated with density stratification, current speed, or pycnocline depth (Fig. 4a, c, d, Table 2 ), and did not fluctuate in relation to tide height (Fig. 4b). Some large changes in the ZCM did correspond to abrupt changes in the physical regime (e.g. $\mathrm{S}$ between profiles 1 and 2 in Fig. 4c) but such correspondences were inconsistent.

The depth-averaged concentration of sea scallop larvae $\left(\right.$ no. $\mathrm{m}^{-3}$ ) trended downward over the 50 h (Fig. 4 e), but more striking were the sinusoidal fluctuations. Comparison with the ZCM series (Fig. 4a) suggests that the fluctuations in larval concentration occurred with a shorter period. The 2 series are short $(n=26)$ for time series analysis, but the patterns in the autocorrelations substantiate this interpretation. After removing the linear trend in the mean larval concentration series,

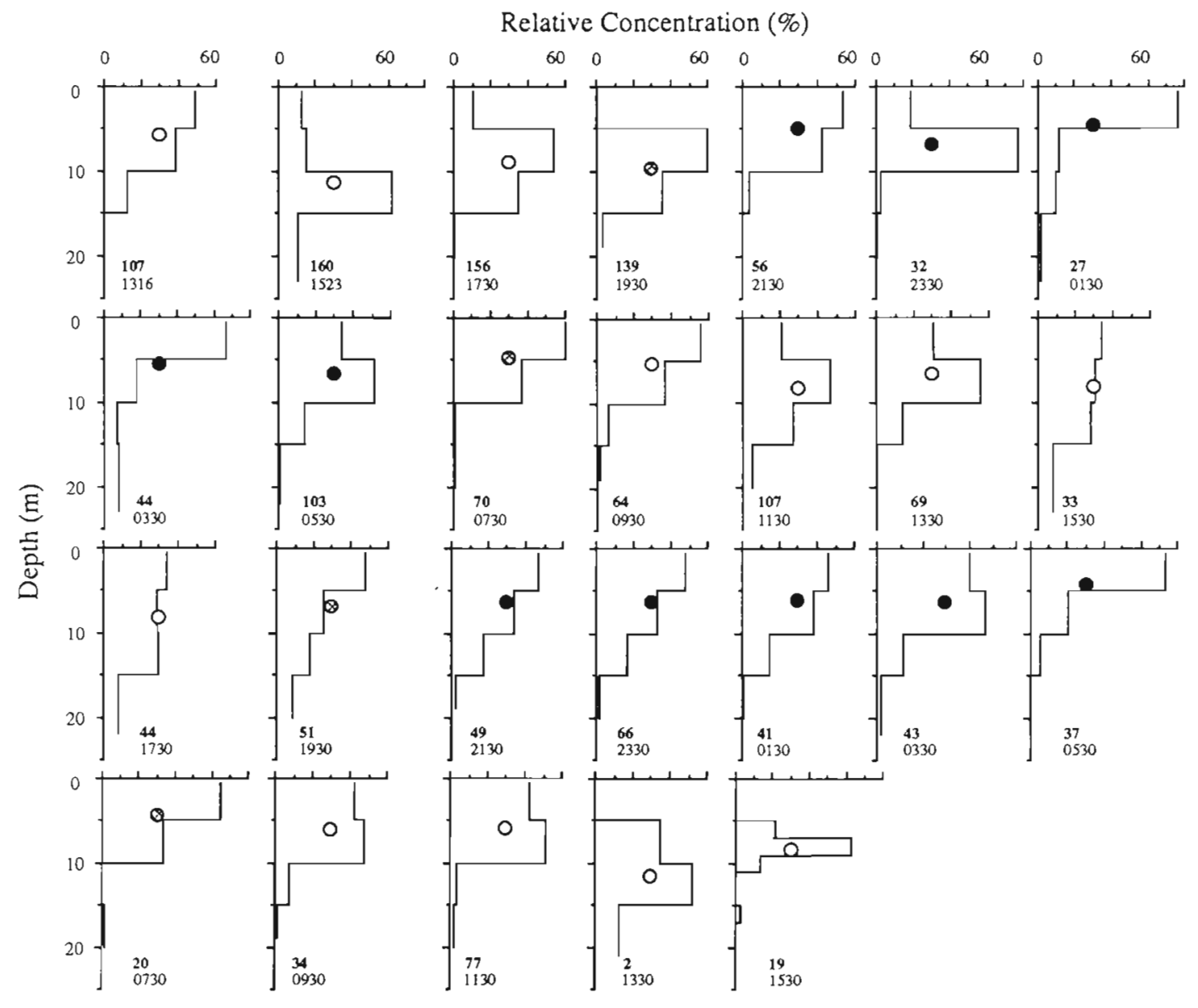

Fig. 3. Placopecten magellanicus. Vertical distribution of sea scallop larvae for individual profiles expressed as relative concentration within each depth interval. Plotted values are the percentage of the larval no. $\mathrm{m}^{-3}$ summed over all 4 depth intervals. Circles show ZCM and are patterned according to light conditions: open indicates day, closed indicates night, and cross-hatched indicates dawn or dusk. At bottom of each profile is time of day (lower number) and larval no. $\mathrm{m}^{-3}$ summed over all depth intervals (upper number). The upper number multiplied by 2.7 approximates the actual number of larvae caught in the profile (since the mean volume sampled per interval was $2.7 \mathrm{~m}^{3}$ ) 

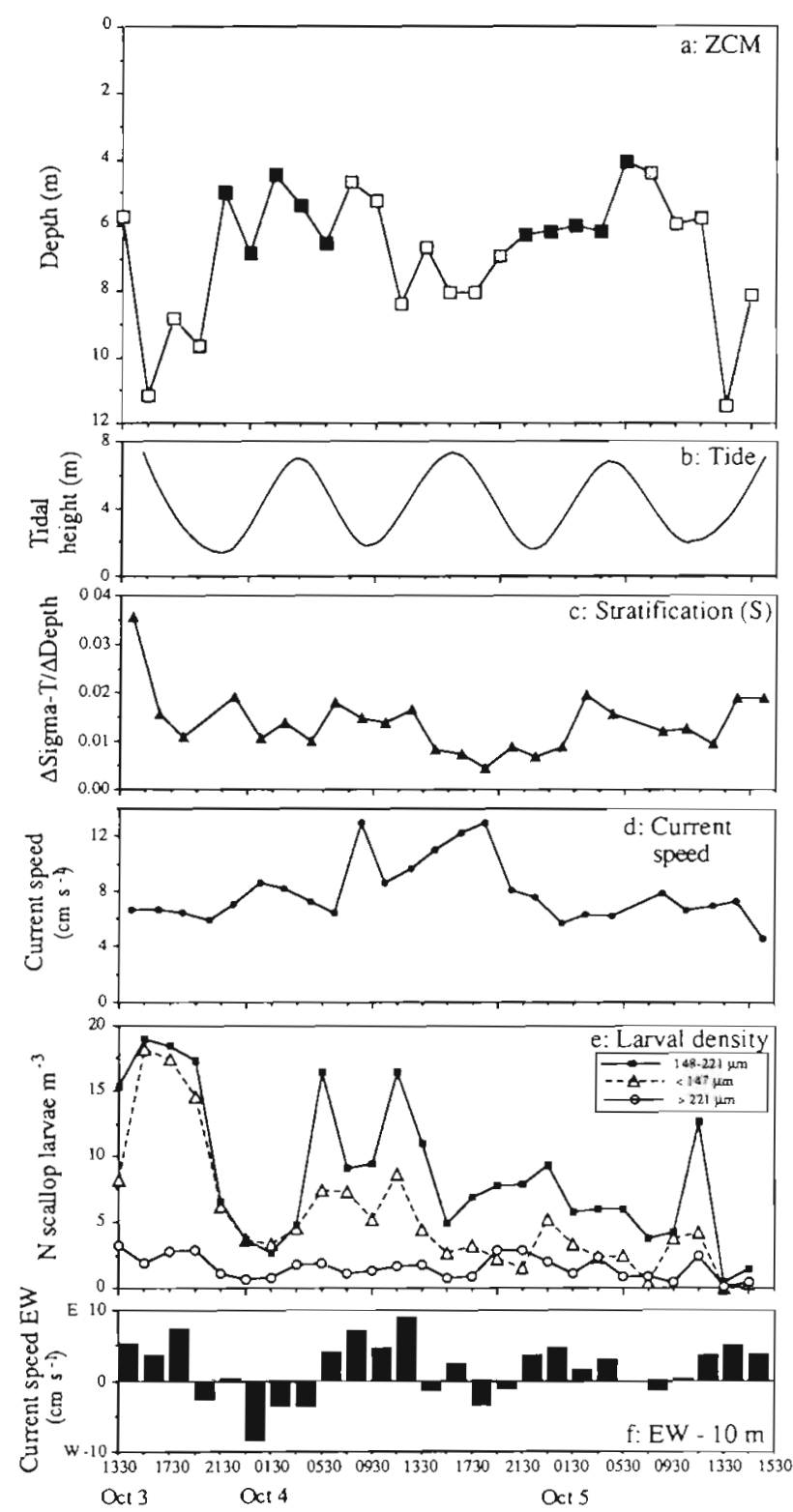

Fig. 4. Placopecten magellanicus. Larval sea scallop distribution and physical variables versus time for the $50 \mathrm{~h}$ anchor station. (a) Larval centre of mass (ZCM) patterned according to light conditions (see Fig. 3 caption); (b) tidal height from tide tables (Saint John, N.B.); (c) index of density stratification $(S)_{i}$ (d) depth-averaged current speed; (e) depth-averaged concentration of 3 size groups of sea scallop larvae; (f) current speed at $10 \mathrm{~m}$, east-west component

peak negative correlations occurred at lags of 6 to $10 \mathrm{~h}$, and peak positive correlations occurred at lags of 16 to $18 \mathrm{~h}$ (Fig. 5a). In the ZCM series, the peak negative correlations occurred at lags of 8 to $14 \mathrm{~h}$ and peak positive correlations at lags of 22 to $26 \mathrm{~h}$ (Fig. 5b). The individual correlations were generally not significant, perhaps because the series were short.

To determine if the changes in current speed were related to fluctuations in mean larval concentration, correlations were run between the latter variable and (1) depth-averaged current and (2) the east-west and north-south components of the current at depths which bracket the larval ZCM (Table 2). The only significant correlation was that between larval concentration and the east-west component of the current at $10 \mathrm{~m}$. Larval concentration was highest when currents at $10 \mathrm{~m}$ were eastward, i.e. out of the embayment (Fig. 4f). The correlation was higher in the first half of the series, with the Spearman correlation coefficient increasing from 0.40 (Table 2) to 0.62 when only the first $24 h$ was used.

Larvae tended to be more dispersed (CVs less than $50 \%$ ) when the stratification index (S) was at its lowest (Fig. 6). Above these low levels of $\mathrm{S}$ there was considerable scatter in the relationship (Fig. 6), and the correlation between larval aggregation and stratification was positive but not significant (Table 2).

A wide size range of sea scallop larvae was present in the water column over the entire 50 h of sampling (Fig. 7) but there was no evidence for size-specific depth distribution. Visual examination of changes in the length frequency distribution with depth indicated no consistent pattern, and the ranked ZCMs of larvae of different size groups did not differ in a systematic fashion over the $50 \mathrm{~h}$ (Table 3 ).

\section{DISCUSSION}

A physical mechanism put forward by de Wolf (1973) to explain short-term variation in the density of barnacle larvae is based on changes in current speed over a tidal cycle and the effect on bottom-dwelling larvae. By this argument, larvae are on or close to the bottom when current speeds are low, and are mixed upwards into the water column as current speeds increase. If this were the case in the present study, the depth-averaged concentration of sea scallop larvae would be expected to be positively correlated with current speed, and negatively correlated with the larval centre of mass (ZCM). This was not the case (Table 2), and larval concentration fluctuated with a shorter period than did the ZCM (Figs. $4 \mathrm{a}$, e and 5). A negative correlation between larval concentration and the ZCM would also be expected if sea scallop larvae were actively dropping out of the water column to rest on the bottom as has been observed in mesocosm studies ( $R$. O'Dor, Dalhousie University, pers. comm.). In the present study it appears that fluctuations in the mean concentration of sea scallop larvae were driven by factors different to those affecting the mean depth (ZCM) of sea scallop larvae.

The strong tides in the Bay of Fundy were probably a factor in the changes in mean larval concentration, and it appears that a patch (or patches) of sea scallop larvae 
Table 1 Placopecten magellanicus. Day-night differences in the depth of the larval centre of mass (ZCM), stratification index (S), and current speed. Profiles corresponding to day-night groups are indicated in Fig. 3. Day-night differences were significant only for the ZCM (Mann-Whitney comparison, $\mathrm{p}<0.05$ )

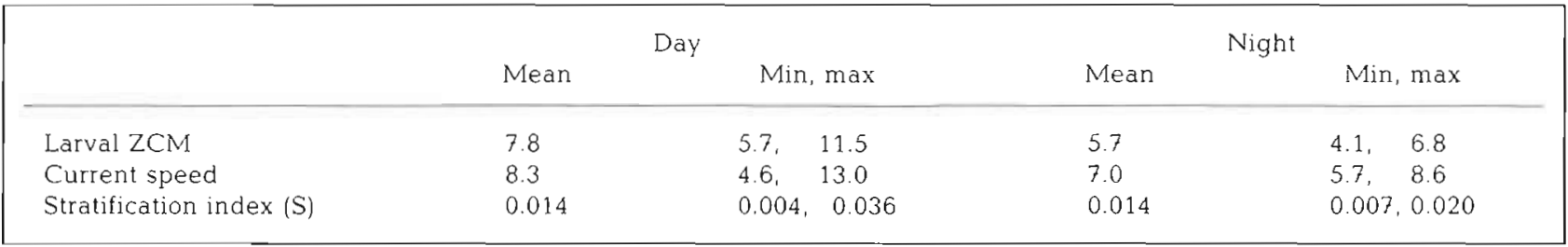

Table 2. Placopecten magellanicus. Spearman rank correlation coefficients for vertical distribution of sea scallop larvae versus physical variables. $N=24$ to 26. Coefficients which are significant ( $5 \%$ level; Sokal \& Rohlf 1969 ) are indicated with an asterix. $\mathrm{N} \mathrm{m}^{-3}$ : concentration of larvae; ZCM: larval centre of mass; CV coefficient of variation; P: depth of pycnocline; S: stratification index; Curr: depth-averaged current speed; NS 4: current speed at $4 \mathrm{~m}$, north-south component; NS 10: current speed at $10 \mathrm{~m}$, north-south component; EW 4: current speed at $4 \mathrm{~m}$, east-west component; EW 10: current speed at $10 \mathrm{~m}$, east-west component

\begin{tabular}{|lcccccrrrr|}
\hline & ZCM & CV & P & S & Curr & NS 4 & NS 10 & EW 4 & EW 10 \\
\hline $\mathrm{N} \mathrm{m}^{-3}$ & 0.22 & -0.21 & -0.14 & 0.04 & -0.13 & 0.18 & 0.06 & -0.15 & $0.40 \cdot$ \\
ZCM & - & -0.36 & -0.04 & -0.08 & -0.15 & -0.19 & 0.05 & -0.13 & 0.17 \\
CV & - & - & -0.31 & 0.25 & -0.11 & 0.14 & 0.02 & -0.30 & -0.27 \\
P & - & - & - & $-0.50 \cdot$ & -0.15 & -0.15 & 0.14 & -0.01 & -0.05 \\
S & - & - & - & - & $-0.44 \cdot$ & 0.02 & -0.18 & $-0.52 \cdot$ & -0.39 \\
Curr & - & - & - & - & - & -0.35 & -0.05 & $0.75 \cdot$ & -0.19 \\
NS 4 & - & - & - & - & - & - & 0.01 & -0.15 & -0.12 \\
NS 10 & - & - & - & - & - & - & - & -0.05 & -0.17 \\
EW 4 & - & - & - & - & - & - & - & - & -0.33 \\
\hline
\end{tabular}

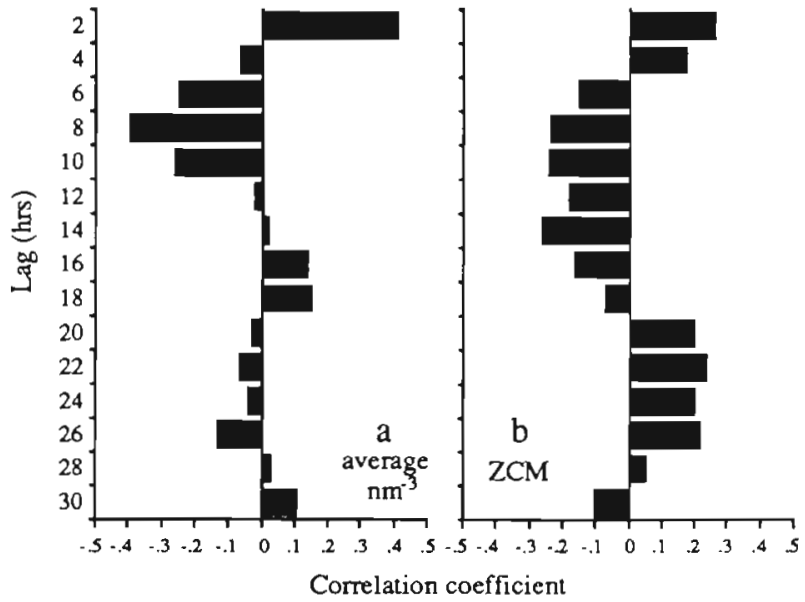

Fig. 5. Placopecten magellanicus. Autocorrelation analyses of (a) depth-averaged concentration of sea scallop larvae, and (b) larval centre of mass (ZCM). $N=26$ for both series. Shown is the Pearson correlation coefficient for lags in the series ranging from 1 to 15 ( 2 to $30 \mathrm{~h}$ since sampling occurred every $2 \mathrm{~h}$ )

was advected back and forth past the anchor station. The positive correlation between larval concentration and the east-west current at $10 \mathrm{~m}$ substantiates this interpretation, as does the autocorrelation analysis of the larval concentration. Although none of the individual correlations were significant in the autocorrelation series, the pattern of correlations was not random

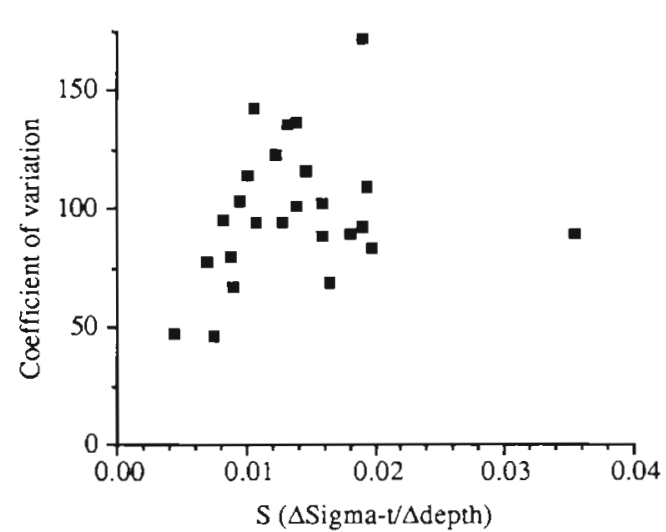

Fig. 6. Placopecten magellanicus. Aggregation of sea scallop larvae (coefficient of variation: $\mathrm{CV}$ ) versus index of water column stratification (S)

(Fig. 5), and peak negative correlations were observed at lags of 6 to $10 \mathrm{~h}$, which would be expected if changes in the tidal current underlied the changes in mean larval concentration.

The length frequency of larvae was fairly consistent over the $50 \mathrm{~h}$ (Fig. 6), indicating either that the same patch of larvae was sampled, or that larvae arriving from contiguous areas had the same length frequency. Adult sea scallops are present throughout the area, and the origin of the larvae found at the $50 \mathrm{~h}$ station is therefore unknown. Based on length frequency, sea 


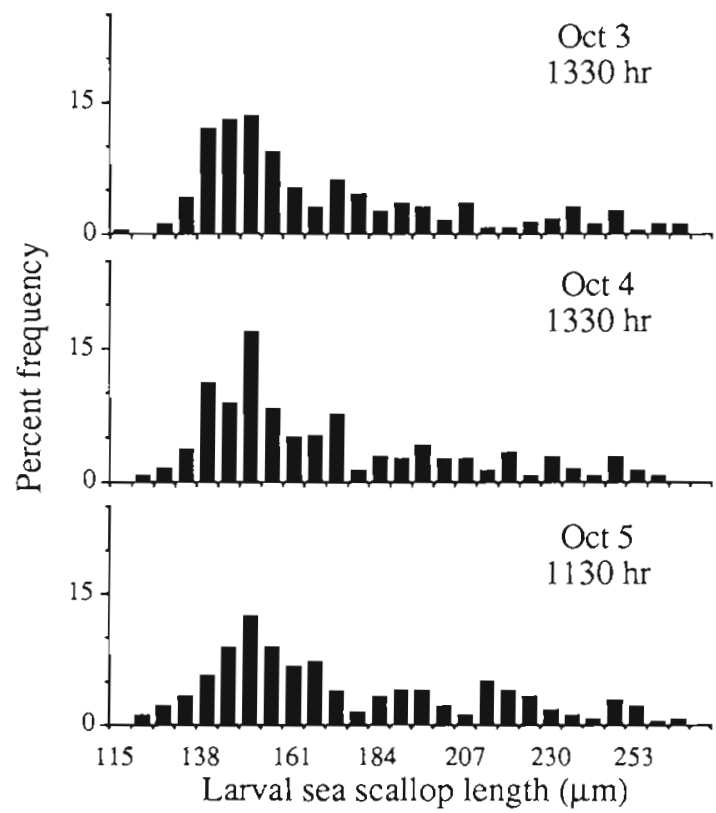

Fig. 7 Placopecten magellanicus. Length frequency of sea scallop larvae, averaged over all depths, at start, middle, and end of sampling

Table 3. Placopecten magellanicus. Day-night values for the larval centre of mass (ZCM) within different length groups The ZCMs of different size groups (within day or night periods) were not significantly different at $p=0.05$ (KruskalWallis test)

\begin{tabular}{lcccc}
\hline \multirow{2}{*}{ Length } & \multicolumn{2}{c}{ Day } & \multicolumn{2}{c}{ Night } \\
\hline$<147 \mu \mathrm{m}$ & Mean & Min, max & Mean & Min, max \\
$148-221 \mu \mathrm{m}$ & 8.2 & $4.3,10.6$ & 5.5 & $3.3,7.2$ \\
$>221 \mu \mathrm{m}$ & 7.4 & $5,6,11.5$ & 5.7 & $4.1,6.8$ \\
& & & \\
\hline
\end{tabular}

scallop larvae collected at the anchor station (Fig. 7) cannot be distinguished from those collected in the outer Bay of Fundy (Tremblay \& Sinclair 1988: Fig. 13). It is assumed here that larvae in contiguous areas have a similar pattern of vertical migration, and that the observed fluctuations in the larval centre of mass (ZCM) would be observed if a single patch of larvae were sampled

The deeper ZCM of sea scallop larvae during the day compared to that of the night (Table 1 ) indicates that a diel vertical migration occurred. The alternative explanation, that the diel changes in the ZCM were caused by corresponding physical changes in the water column, is not tenable because there were no significant day-night differences in stratification (S) or current speed (Table 1), and no significant correlation between the ZCM and any of the physical variables (Table 2 ).

The apparent amplitude of the vertical migration was small (Table 1). Depth-stratified sampling may under- estimate the amplitude of migration if individual larvae are migrating at different times (Pearre 1979), but the bimodal distributions typical of such migratory asynchrony were not apparent in the present study (Fig. 3). Depth-stratified sampling may also underestimate the amplitude of migration if the width of the sampling strata ( $5 \mathrm{~m}$ in the present study) is substantially greater than the true width of the larval aggregations. Finer scale sampling is required to resolve this question. A small amplitude vertical migration of scallop larvae into shallower waters at night is consistent with observations under controlled conditions. In a $10 \mathrm{~m}$ mesocosm, sea scallop larvae moved from a mean depth of $6.9 \mathrm{~m}$ during the day to $3.7 \mathrm{~m}$ at night (Silva \& O'Dor 1988), and Pecten maximus larvae also occur shallower at night in experimental water columns (Kaartvedt et al. 1987). Field studies of other species of bivalve larvae (Quayle 1952, 1959) and total bivalve larvae (Harding et al. 1986. Scrope-Howe \& Jones 1986) have also found this pattern

The relationship between larval aggregation $(\mathrm{CV})$ and density stratification (S) (Fig. 6) is similar to that which was observed for Georges Bank (Tremblay \& Sinclair 1990). In both studies sea scallop larvae were dispersed evenly over the water column (low CV) at low levels of density stratification ( $S$ values of 0.008 to 0.006 ). It appears that there is a critical level of water column stratification below which sea scallop larvae are unable to form aggregations, and that this level of stratification is common to different areas. Presumably this critical level of stratification is reached when the swimming speeds of the larvae can no longer overcome the increased turbulence associated with low stratification.

Larval behaviour underlies both the formation of aggregations and the vertical migration observed in this study. Because the swimming behaviour of scallop larvae is to some extent size specific (Cragg 1980, Silva \& O'Dor 1988) it might be expected that some depth stratification by size would be observed in nature. For example larvae capable of metamorphosis (ca 230 to $290 \mu m_{i}$ Culliney 1974) would be expected to be close to the bottom, searching for appropriate settlement locations. This study and those in the Bay of Fundy and on Georges Bank (Tremblay \& Sinclair 1988, 1990) have found little evidence for stratification by size. It may be that this is a real phenomenon and that turbulence in these tidally energetic areas is usually too great for size-specific swimming behaviours to manifest themselves. Alternatively the depth intervals sampled are too coarse, or the sampler is unable to get close enough to the bottom to sample late-stage larvae.

The patterns of diel vertical migration, and hypotheses regarding its adaptive value, have been extensively reviewed (e.g Russell 1927, Cushing 1951, McLaren 1963, Banse 1964, Longhurst 1976). These 
hypotheses may be characterized as involving one of the following features: (1) the avoidance of predation, (2) increased ability to locate food, (3) the use of vertical shear for transport or retention, (4) demographic or energetic advantages, and (5) avoidance of competition. Vertical migration must confer different selective advantages for different species. To evaluate the advantage of vertical migration to sea scallop larvae, more needs to be known about their predators, the distribution of their preferred food, and the physical circulation where they are studied. This paper shows that a small amplitude vertical migration of sea scallop larvae can occur in some areas, and that the effect of this migration should be considered in models of larval transport.

Acknowledgements. We thank the captain and crew of the 'Lady Hammond' for making the sampling possible, and D. Meade, S. Wilson and D. Duggan for assistance during sampling or in the laboratory. Physical and Chemical Sciences Branch is thanked for the use of their portable current meter R. Miller, G. Robert, S. Wilson and 3 anonymous reviewers are thanked for their reviews of the manuscript. This work forms part of a Ph.D. thesis to be submitted to the Dept of Biology, Dalhousie University, by M. J. Tremblay.

\section{LITERATURE CITED}

Andrews, J. D. (1983). Transport of bivalve larvae in James River, Virginia. J. Shellfish Res. 3: 29-40

Banse, K. (1964). On the vertical distribution of zooplankton in the sea. Prog. Oceanogr. 2: 55-125

Carriker, M. R. (1951). Ecological observations on the distribution of oyster larvae in New Jersey estuaries. Ecol. Monogr. 21: 19-38

Cragg, S. M. (1980). Swimming behavior of the larvae of Pecten maximus (L.) (Bivalvia). J. mar. biol. Ass. U. K. 60: 551-564

Culliney, J. L. (1974). Larval development of the giant sea scallop Placopecten magellanicus (Gmelin). Biol. Bull. mar biol. Lab., Woods Hole 147: 321-332

Cushing, D. H. (1951). The vertical migration of planktonic crustacea. Biol. Rev. 26: 158-192

Fortier, L., Leggett. W. C. (1982). Fickian transport and the dispersal of fish larvae in estuaries. Can. J. Fish. Aquat. Sci. 39: 1150-1163

Harding, G. C., Vass, W. P., Hargrave, B. T., Pearre, S., Jr (1986). Diel vertical movements and feeding activity of zooplankton in St. Georges Bay, N.S., using net tows and a newly developed passive trap. Can. J. Fish. Aquat. Sci. 43: 952-967

Kaartvedt, S., Aksnes, D. L., Egge, J. K. (1987). Effect of light on the vertical distribution of Pecten maximus larvae. Mar. Ecol. Prog. Ser. 40: 195-197

Kamykowski, D. (1976). Possible interactions between phytoplankton and semidiurnal internal tides. II. Deep thermoclines and trophic effects. J. mar. Res. 34: 499-509

Korringa, P. (1952). Recent advances in oyster biology. Q. Rev. Biol. 27: 266-308

This article was presented by Dr G. C. Harding, Dartmouth, N.S., Canada
Kunkle, D. E. (1958). The vertical distribution of oyster larvae in Delaware Bay. Proc. natn. Shellfish. Ass. 48: 90-91

Longhurst, A. R. (1976). Vertical migration. In: Cushing, D. H., Walsh, J. J. (eds.) Ecology of the seas. Blackwell Scientific Publications, Oxford, p. 116-137

Lough, R. G., Trites, R. W. (1989). Chaetognaths and oceanography on Georges Bank. J. mar Res. 47: 343-369

Mann, R., Wolf, C. C. (1983). Swimming behavior of larvae of the ocean quahog Arctica islandica in response to pressure and temperature. Mar Ecol. Prog. Ser 13: 211-218

McLaren, I. A. (1963). Effects of temperature on growth of zooplankton, and the adaptive value of vertical migration. J. Fish. Res. Bd Can. 20: 685-627

Mileikovsky, S. A. (1973). Speed of active movement of pelagic larvae of marine bottom invertebrates and their ability to regulate their vertical position. Mar. Biol. 23: $11-17$

Nelson, T C., Perkins, E. B. (1931). Annual Report of the Department of Biology for the year ending June 30, 1930. N. J. Agric. Exp. Sta. Bull. 522: 1-47

Pearre, S. Jr. (1979). Problems of detection and interpretation of vertical migration. J. Plankton Res. 1 29-44

Quayle, D. B. (1952). Structure and biology of the larva and spat of Venerupis pullastra (Montagu). Trans. R. Soc. Edinb. 62: 255-297

Quayle, D. B. (1959). The early development of Bankia setacea Tryon. In: Ray, D. L. (ed.) Marine boring and fouling organisms. Univ. Washington Press, Seattle, Washington, p. $157-171$

Rothlisberg, P. C. (1982). Vertical migration and its effect on dispersal of penaeid shrimp larvae in the Gulf of Carpentaria, Australia. Fish. Bull. U.S. 80: 541-554

Rothlisberg, P. C., Church, J. A., Forbes, A. M. G. (1983). Modelling the advection of vertically migrating shrimp larvae. J. mar Res. 41. 511-538

Russell, F. S. (1927). The vertical distribution of plankton in the sea. Biol. Rev. 2: 213-262

Scrope-Howe, S., Jones, D. A. (1986). The vertical distribution of zooplankton in the Western Irish Sea. Estuar coast. Shelf Sci. 22: 785-802

Silva, M. A., O'Dor, R. K. (1988). Active depth regulation by the sea scallop larvae of Placopecten magellanicus? Bull. Can. Soc. Zool. 19 (2): 36 (Abstract)

Sokal, R. R., Rohlf, F. J. (1969). Biometry. W. H. Freeman and Co., San Francisco

Tremblay, M. J., Meade, L. D., Hurley, G. V. (1987). Identification of planktonic sea scallop larvae (Placopecten magellanicus) (Gmelin). Can. J. Fish. Aquat. Sci. 44: 1361-1366

Tremblay, M. J., Sinclair, M. M. (1988). The vertical and horizontal distribution of sea scallop (Placopecten magellanicus) larvae in the Bay of Fundy in 1984 and 1985. J. Northw. Atl. Fish. Sci. 8: 43-53

Tremblay, M. J., Sinclair, M. M. (1990). Sea scallop larvae Placopecten magellanicus on Georges Bank: vertical distribution in relation to water column stratification and food. Mar. Ecol. Prog. Ser 61: 1-15

Verwey, J. (1966). The role of some external factors in the vertical migration of marine animals. Neth J. Sea Res. 3 : 245-266

Wolf, P. de (1973). Ecological observations on the mechanisms of dispersal of barnacle larvae during planktonic live and settling. Neth. J. Sea Res. 6: 1-129

Manuscript first received: April 8, 1990

Revised version accepted: July 4, 1990 